\title{
Overcoming of Information Extremism as a Condition of Human and Social Wellbeing
}

\author{
Vladimir A. Ponomarev ${ }^{\mathrm{a}}$, Alla A. Kornienko ${ }^{\mathrm{b} *}$, Tatiana S. Kust ${ }^{\mathrm{a}}$, Evgeny S. \\ Terentyev $^{a}$, Victoria V. Litvinenko ${ }^{\text {a }}$ \\ * Corresponding author: Alla A. Kornienko, allaphil@tpu.ru \\ ${ }^{a}$ Yurga Institute of Technology, TPU affiliate, Yurga, Russia \\ ${ }^{b}$ Tomsk Polytechnic University, Tomsk, Russia, E-mail: allaphil@tpu.ru, Tel.: +7-382-256-3526
}

\begin{abstract}
http://dx.doi.org/10.15405/epsbs.2016.02.6

The urgency of this research is indisputable because the subjects of information extremism having at their disposal various mass media can disseminate their beliefs and ideas over thousands of people in different countries all over the world. International collaboration is needed to struggle against this evil. The paper provides deep insight into the notion "information extremism", as well as its classification and forms. It is aimed at revealing the specific character of the notions "information extremism" and "information terrorism" and their investigation. Illocutionary influence as the major method of information extremism is highlighted in the paper. The authors demonstrate important influence of mass media including the Internet over readership, especially the youth. It is concluded that the issue of information extremism requires for more rigorous and deeper consideration. It is necessary to fight against forms of its manifestation, because they have a significant effect on homeland and international safety and stability.
\end{abstract}

(C) 2016 Published by Future Academy www.FutureAcademy.org.uk

Keywords: Information extremism; propaganda; illocutionary influence; crimes; information security; extremist communities; mass media; terrorism.

\section{Main text}

The actual state of human society raises a topical question of information extremism and its overcoming and calls scientific community to discuss these problems. The papers of the following foreign authors are well-known in this sphere: P. Purpura (2006), W. Dyson(2001). B. Akhgar, \& A. Staniforth, \& F. Bosco(2014), L. Voytasik (1981), M. Szulczewski (1972), S.M. Mukhametzhanova (2014) et al.

\section{(i) $\odot$}

EY NC ND This is an Open Access article distributed under the terms of the Creative Commons Attribution-Noncommercial 4.0 Unported License, permitting all non-commercial use, distribution, and reproduction in any medium, provided the original work is properly cited. 
In works of Russian scientists: G. T. Zhuravlev(2009), E. V. Kovalevskaya(2009), G. G. Pocheptsov(2000), O. I. Dashkova(2005), A. Rabodzey(2005), A. N. Kurbatsky(2008), G. S. Vechkanov(2005) et al we also can find their deep concern about this problem and ways to overcome information extremism thought of an extremely dangerous and effective weapon directed against the mankind.

Development of the society, private ownership, state system and struggle for power alongside with further widening of human activities are the reasons for more valuable character of information, especially of this one, which can assure its owners obtaining any benefits: ethical, material, political military ones etc. (G. T. Zhuravlev, \& E. V. Kovalevskaya 2009)

Information war both stresses the importance of audience and focuses on searching for vulnerably spots of mass conciseness (Pocheptsov, G.G. 2000)

Information extremism is one of the most wide-spread types of extremism these days. At the same time it is less investigated and comprehended then the others.

As the reasons the following ones can be mentioned.

First, in most cases the modern world doesn't overestimate the danger of this phenomenon, because direct acts of terrorism (explosions, arsons, seizure of hostages, mortgages of high-ranking officials etc.) are supposed to be the worst threats for the mankind. The radical information impact is the issue of minor importance without lethal impact on people, in other words, it doesn't directly threaten human life or health.

Second, information extremism is hardly to notice. It can be compared with the wind, blowing in different directions. The source of it is also difficult to determine "where the wind is blowing from"from ventilator or it is a natural phenomenon.

In terms of the aforementioned reasons information extremism is often considered alongside with PR-technologies, propaganda, and other forms of illocutionary influence on the audience. In fact, information extremism being a form of manifestation of illocutionary influence can't be reduced to it, but includes extremist characteristics as well.

In this connection quite natural questions arise: what extremism is and what illocutionary influence is. How can these phenomena give one general concept - information extremism?

Formerly, the form of professional extremism included such distinctive features as following one ideology and aspiration for national liberation, acting according to definite political purposes and open financing by ruling elites in some countries.

Nowadays this habitual form is gradually disappearing. Information extremism is taking this place through forcing it out. Here one extreme-conscious person may be more destructive than the largest extremist groups.

Information extremism has been just gathering speed now, but in future it can be on the world stage. The age of this phenomenon hasn't arrived yet, but unfortunately this type of extremism has its future taking into account the current level of informational technologies. Therefore, we know its possibilities and they are not restricted. 
The damage of houses and symbols of the present regime are not basic weapons of this type of extremism. It focuses on damaging the communications. It can lead to chaos in current information society.

At the same time we have to consider, that the extremist forces are not the only ones who can destruct data communications. Counterextremist forces also can damage data communications between the members of an extremist group. As the result, both its destabilization and temporary stoppage of its activity are possible.

We know two forms of information extremism.

The first one is "sabotage". It is directed at destruction of data communications.

The second one is more complicated. It is aimed at erosion of values and traditions in society via informational technologies. The worst form of information extremism is information terrorism.

It is unfolded in the sphere of political, philosophical, legal, aesthetic, religious and other ideas and beliefs i.d. in the sphere of battle of ideas. Information terrorism is, first of all, a form of negative effect on the personality, society and state by means of all kinds of information. Its aim is to weaken and loosening the constitutional system. Various forces are engaged in this process, as well as different methods are used - from agents of foreign secret services to domestic and international mass media (Dashkova, O. I. 2005).

As an example of this type of extremism Osama Bin Laden - leader of Al Qaeda speech after the $11^{\text {th }}$ September can be mentioned. Then, in the USA a lot of people were dissuaded from ability of their state to protect its citizens.

The community on the whole can be a subject of this information extremism form. Although an extreme-conscious person can play an important part here. Illocutionary impact is thought of his main method. Without striving for power over the minds for the sake of the power or covering-up his own aims, he wants to change an existing world order and speaks openly, being afraid of nobody.

Being aware of hidden character of illocutionary impact on the object, as the aspect of theory of illocutionary influence, we can entirely apply it to the research into information extremism. It is considered as a communication unequal in rights, and extremist organizations as the subjects of this communication. Therefore, research into information extremism necessitates concurrent discussion of power of language with speech manipulations and unethical relation to the object. Different mechanisms are used within this phenomenon: linguistic demagogy, propaganda etc.

At the same time one have to take into consideration that illocutionary impact is always planned with a particular purpose. The essence of this purpose depends on the specific grounds in some cases caused by the psychological state of a speech holding person. That is, the purpose of any illocutionary influence over the object is to motivate him/her for a definite action, which subsequently will meet the requirements of the subject of illocutionary influence. Information extremism has one general purpose only - to obtain power over the minds, attracting new extremists or spark panic among the population.

Exact wording and explanation of own attitudes, search for and unity of supporters, struggle against the enemies - these activities determine the content of extremist communication being the purpose of the second form of information extremism - struggle for power. Specific subject-object correlation is 
the basis to study illocutionary impact in extremist discourse, because the distance between them has a social character and depends on the external factors.

We know that some individuals and groups of population can be subject to extremist illocutionary influence. It is obviously considered together with mass suggestion and persuasions in extremist discourse. It owes to the desire of extremist groups to make the extremist audience as innumerable as possible. In this case definite knowledge meeting the requirements of an extremist group is integrated into the world model of each person-object.

As the issue of mass consciousness is a multifaceted one, we have to concentrate on the subject of illocutionary influence within this paper, to be more precise - on the correction of his/her values. It is worth mentioning that communication of extremists with recipients has an indirect character in most cases. This fact is explained by the necessity to effect on a big number of people (this influence is impossible without channels of mass communication). The communicative role of the subject of illocutionary influence is also changed: a definite image abstracts away from the personality of an extremist and includes both real features of a personality, and projections of qualities, reflecting interests of his/her potential supporters, i.d. his/her image.

At the same time, the object perceives the image, which is constantly reproduced by the subject and mass media. Here the mass character of the object influences on the relation of subject to the object. A subject acts a specialized, specific one. That is why he realizes his self-importance and his particular part in this communication. The object of illocutionary influence in political discourse is thought of being a depersonalized mass without any special age, sex and professional differences. It consolidates the idea of the subject of political influence concerning his active communicative position.

As far as we know, propaganda is a form of illocutionary influence in extremist discourse. As Polish writer and author of many well-known works L. Voytasik(1981) thinks propaganda is to be directed on explanation of environment to people. The other Polish scientist M. Szulczewski (1972) says that propaganda is a goal-directed and politically motivated persuasive influence on social groups. On its basis special social-political ideas, beliefs, and theories are transferred to each person's mind and effect on development of his/her behavior in required direction.

Here, it is worth emphasizing, that the second definition makes it explicit that propaganda is a politically motivated activity and completely supports particular social classes in achieving and strengthening their ideological, political and social supremacy.

At the same time, in spite of mentioned above definitions of propaganda as a persuasion, a lot of scientists suppose that the essence of propaganda is manipulation or suggestion, as well as emphasize its ideologizing character becoming apparent in the statement "who is not with us that is against us". As an example of propaganda floating a rumor can be considered that biological weapon is accessible for everyone, including extremists. In 2000 one of former directors of CIA (the USA), James Vusley said that any school student with the most B grades could produce biological agents.

Starting in 2001 information wave concerning the threat of bioterrorism in the USA gave a definite gain to some agencies and organizations: special services obtained financial support to struggle against potential threats and establish structures to fight against bioterrorism in a new department - Homeland Security, mass media got a new subject to discuss and pharmaceutical companies - multimillion orders 
http://dx.doi.org/10.15405/epsbs.2016.02.6

eISSN: 2357-1330 / Corresponding Author: Alla A. Kornienko,E-mail: allaphil@tpu.ru

Selection and peer-review under responsibility of the Organizing Committee of the conference

to produce vaccines. The branch of biotechnologies obtained a great stimulus to work in the sphere of bio-detection and analysis of genetic material. At the same time, over a period of common hysteria materials were developed, which dealt with ephemerality of threats and various prognosis of damage caused to biotechnology by struggle against bio-terrorism (Rabodzey, A. 2005).

Finally, the question is open, if the situation like the mentioned above can be considered as aiding and abetting to extremism and its purposes by official authorities. The result is that information extremism can be caused by both members of criminal groups and by stronghold of counter-extremism - official authorities of state security. Mass media making an attempt to raise their rating through growing amount of violence on the screen entirely meets the requirements of extremism these days. As the consequence, such application of mass media furthers formation of a new ideology in the society ideology of violence. And extremists, provoking mass media by their actions, continue to increase number of their offences, as they are absolutely sure that their activity will be covered in all mass media. Therefore, in this way they arrive at their improper goal - to win in information war.

That is, terrorist organizations are making an attempt to give a new model of economic and political life regulations to the society via application of informational and political personal violence, which is becoming the basic method of governing the society and its institutions (Kurbatsky, A.N. 2008).

Here the question arises where the differences between information extremism and other types of illocutionary influence are. First of all, they include all the mentioned above distinctive features of extremism. The influence on the subject is not a purpose but a method to achieve it. This basic purpose isn't hidden by the extremists; on the contrary, it is presented as the basis of their activity. They give publicity to the facts, which legitimate mass media try to conceal via influencing over the audience with scenes of violence and open character of their ideas.

Currently the issue of information extremism over values of the society is increasingly important. That is why, that possibility of informational impact on individual and public consciousness including information wars is typical for contemporary stage of informational relations. As the result, the issue of informational security is an unavoidable counterbalance of information freedom.

Extremist forces, seizing new spheres of information space are succeeded in cultivating their axiological attitudes in a broad audience. In conclusion, we can say that information extremism is a ground for other types of extremism. It creates a favorable environment for distribution and acceptance of extremist ideas and ideals.

As the result, mechanisms of illocutionary influence open boundless possibilities to influence over development of the society. That is, information extremism often provokes a great number of extremists-dilettantes to appear. Formerly, the desire to act as an extremist could be realized provided that required training, access to weapons and knowledge, as well as motivation for acts were available. Extremism was not easy to access or anything to be popularized. Nowadays extremist methods are quite generally accessible and can be found in bookshops or in the Internet.

The Internet, without territory borders provides an access to information, which is prohibited for distribution in any way (Mukhamedzhanova, S. M. 2014).

The young are getting Internet addicts. Like any other social phenomenon it has considerable negative aspects. The youth spends more time in front of the computer, preferring virtual reality to the 
objective one, whereas the form of virtual world is the worst one, created by aggressive computer plays. "Live pictures" on the screens of TV and on monitors are merely the same. Murder and violence are practically the standards of life (Kurbatsky, A.N. 2008).

Stating this obvious fact we can say that extremism has been practically accessible for everyone dissatisfied both as an ideology and as a method to perform their acts to express this disappointment. Following the guide how to produce bombs an extremist-dilettante can be as dangerous in terms of damaging and being lethal as his professional colleague. On the other hand, he is getting hard to be retraced and foretold.

The changing structure of extremist groups themselves is one more consequence of information extremism dissemination. There was a strict hierarchy within one group or cell some time ago, but now extremist group has a net form of leadership, which is possible due to development of communications. It means that extremists are not headed by one charismatic leader, dictating his ideology and strategy to the whole group. Today several leaders within one group are possible. They are scattered over the large territory and each of them has his own sources of financing.

As the result, the possibility to foresee and counteract this kind of extremist groups is reduced many times. On the other hand, occurrence and dissemination of a net structure like this one makes an extremist group vulnerable to attacks, because counter-extremist forces will focus on destruction of communications between cells of the group.

Hence, specific character of contemporary extremism is determined by external and internal reasons, forming the situation. Here, negative extremism is a mass phenomenon. Its external factors include development of informational technologies and increasing power of mass media in the society. Among internal reasons one can find the lack of proper ideological education of the youth. These reasons form the trends in modern extremism: changing ideological basis and purposes of extremist groups, as well as occurring information extremism, which has changed the subject of extremism and forms of his activity.

Constant threats influence on the issues of information security, and measures to achieve it. They are directed to prevent these threats or to eliminate the existing ones. These issues can be classified as follows: legal, organization and economic; and technological (Vechkanov, G. S. 2005).Physiological measures can also be considered in this line.

Overcoming information extremism is one of the main problems for leaders all over the world. We know that this phenomenon is a good fundamental for involvement of the youth into criminal extremist communities.

Information extremism in all his forms can be classified as a criminal act, having considerable destructive force and influence on human minds and the society. That is why we have to apply all our reserves to withstand this evil in order to provide conditions for prosperous life both of an individual and of the society on the whole.

At present assuring information security has a considerable effect on homeland and international safety and stability. International collaboration has a special importance in this context because cyberthreats can't be withstood by any state alone. To fight against the cyber-criminals an integral approach is to be applied, addressing all levels of security assurance. 


\section{Acknowledgements}

The author would like to thank the anonymous referees for their constructive and useful comments on the paper.

\section{References}

Purpura, P. (2006) Terrorism and homeland Security. An Introduction with Applications. 512.

Dyson, W. (2001) Terrorism. An Investigator's Handbook. 528.

Cyber Crime and Cyber Terrorism. Investigator's handbook. (2014) Edited by B. Akhgar, A. Staniforth, F. Bosco. 306.

Voytacik, L. (1981) Psychology of political propaganda. 281

Szulczewski, M. (1972) Propaganda polityczna. Zarys problem atyki teoretycznej. In: Wyd. II., poprawiono i rozszerzone. Warszawa, 366

Mukhamedzhanova, S. M. (2014) Assurance of international information security in the Internet In: Scientific journal. Series "Juridical sciences". 1-2 (18-19), 526-529.

Zhuravlev, G. T., Kovalevskaya, E. V. (2009) Information security in a megapolis In: II International scientific and practical conference "Innovative development of Russian economy": Collective papers / Moscow State University of Economics, Statistics, and Informatics. 371-373.

Pocheptsov, G.G. (2000) Information wars. Moscow. 576.

Dashkova, O. I. (2005) Information terrorism in conditions of economic crisis. In: II International scientific and practical conference "Innovative development of Russian economy": Collective papers / Moscow State University of Economics, Statistics, and Informatics. Moscow. 370-371.

Rabodzey, A. (2005). The threat of biological terrorism: importance of mass media. Nuclear control. Journal of PR-Center of political investigations. 11, 3 (77), 87-94.

Kurbatsky, A.N. (2008) Systematic actualization of the problem of personal information security. Materials of the third international scientific conference on the problems of safety and terrorism withstanding. Moscow State Lomonosov University. Moscow. 110-117.

Vechkanov, G. S. (2005) Economic security. SPb.: Vector. 256. 